\title{
Cerebral Hypoperfusion Increases Estrogen Receptor Abundance in the Ovine Fetal Brain and Pituitary
}

\author{
Charles E. Wood \\ Department of Physiology and Functional Genomics, University of Florida College of Medicine, Gainesville, Fla., USA
}

\author{
Key Words \\ Ischemia $\cdot$ Estradiol $\cdot$ Hypoperfusion
}

\begin{abstract}
Background/Aims: Estrogen is an important component of fetal neuroendocrine function in late-gestation fetal sheep; however, little is known about the regulation of estrogen receptor abundance in the brain and pituitary of fetuses. The present study was performed to test the hypotheses that estrogen receptor abundance in the fetal brain and pituitary are influenced by circulating estradiol concentrations and that they are acutely regulated after cerebral hypoperfusion. Methods: We studied 16 time-dated fetal sheep (124-128 days gestation) that were chronically catheterized and instrumented at least 5 days before study. Four groups $(n=4$ each) were studied in which fetuses received estradiol ( 0.25 $\mathrm{mg} /$ day, producing physiological increases in fetal plasma estradiol concentrations) or placebo implants, and in which fetuses received a 10-min period of brachiocephalic occlusion $(\mathrm{BCO})$ or sham-BCO. One hour after BCO or sham-BCO, fetuses were euthanized and tissues rapidly removed for analysis of estrogen receptors (ER) $-\alpha$ and $-\beta$ at the mRNA and protein levels. Results: Both BCO and estradiol treatment were effective in changing ER expression, although the effects were region-specific. BCO dramatically increased ER- $\alpha$ in the pituitary and both ER- $\alpha$ and ER- $\beta$ in the brainstem, while decreasing ER- $\alpha$ expression in the hypothalamus. Estradiol treatment decreased ER- $\alpha$ expression in the
\end{abstract}

hypothalamus, whereas it increased ER- $\alpha$ expression in the brainstem, cerebral cortex and hippocampus. Conclusions: We conclude that the expression of ER- $\alpha$ and ER- $\beta$ in the brain and pituitary of fetal sheep are influenced by circulating estrogen concentrations and acutely regulated in response to cerebral hypoperfusion.

Copyright $\odot 2007$ S. Karger AG, Basel

\section{Introduction}

Estrogen is a key component of fetal endocrine function in late-gestation fetal sheep. Little is known about the mechanisms controlling estrogen receptors in the ovine fetal brain and pituitary. We have recently reported the presence and ontogenetic regulation of both forms of the estrogen receptor (ER- $\alpha$ and ER- $\beta$ ) [1]. Changes in the abundance of both receptors in the hypothalamus, pituitary, hippocampus, and brainstem suggest that the sensitivity of these tissues is likely to change as the fetus matures. ER- $\alpha$ mRNA increases in the brainstem, cerebral cortex, and hippocampus of adult sheep and in the hypothalamus of 1-week-old lambs compared to 145-day fetal sheep [1]. This creates the potential for a change in estrogen signaling, with both plasma concentrations and receptor abundances increasing simultaneously.

The physiological variables important for the control of estrogen receptor expression in the fetal brain are unknown. The effect of increases in circulating estradiol

\section{KARGER}

Fax +41613061234

E-Mail karger@karger.ch

www.karger.com
(C) $2007 \mathrm{~S}$. Karger AG, Basel

$0028-3835 / 08 / 0874-0216 \$ 24.50 / 0$

Accessible online at:

www.karger.com/nen
Charles E. Wood, $\mathrm{PhD}$

Department of Physiology and Functional Genomics

University of Florida College of Medicine, P.O. Box 100274

Gainesville, FL 32610-0274 (USA)

Tel. +1 352392 4488, Fax +1 352392 8340, E-Mail cwood@phys.med.ufl.edu 
concentrations on the abundance of estrogen receptor forms in the fetal brain is unknown. Specifically, it is not known whether receptor abundance is downregulated in response to estrogen as it is in the mammary gland, brain, and pituitary in adult rats and mice [2-5]. If so, it is possible that the influence of estrogen on receptor abundance is specific to different brain regions, and it is possible that the regulation of the receptor is different in the fetus compared to the adult. In addition to the possible regulation of estrogen receptor expression by estrogen, dynamic responses of the estrogen receptor after fetal stress can also occur. In fetal sheep, reduction of cerebral perfusion pressure decreases cerebral blood flow [6] and stimulates neuroendocrine responses [7]. Estrogen is reportedly neuroprotective during cerebral ischemia in adult animals [8]. Alteration of estrogen receptor abundance in response to cerebral hypoperfusion might provide a mechanism for countering the destructive effects of repeated bouts of cerebral ischemia.

The present study was designed to investigate both the separate and combined effects of estradiol treatment and cerebral hypoperfusion. In chronically catheterized fetal sheep, we measured the expression of both $\alpha$ and $\beta$ forms of the estrogen receptor (ER- $\alpha$ and ER- $\beta$ ) at both the mRNA and protein levels in the pituitary and in brain regions which are important for regulating cardiovascular and neuroendocrine reflex responses to hypotension. We tested the hypothesis that estradiol treatment downregulates both ER- $\alpha$ and ER- $\beta$ in the fetal brain and pituitary, and that the response to estrogen is modulated by cerebral hypoperfusion.

\section{Materials and Methods}

We studied 16 time-dated fetal sheep between 124 and 128 days' gestation at the time of experimentation. Hemodynamic, hormonal, and other gene expression data from these experiments have been reported previously [9-11]. These experiments were approved by the University of Florida Institutional Animal Care and Use Committee.

\section{Fetal Surgery}

Using an aseptic surgical technique, we implanted indwelling vascular and amniotic catheters and extravascular occluders in utero into each fetus. As previously described [6], we placed catheters in the femoral and lingual arteries bilaterally and in the amniotic cavity. We placed an extravascular occluder (OC8, In Vivo Metric, Healdsburg, Calif., USA) around the brachiocephalic artery via the second intercostal space. In one half of the fetuses $(\mathrm{n}=8)$, we implanted a pellet containing estradiol subcutaneously at the mid-scapular level, and in the other half $(n=8)$, we implanted a placebo pellet (containing cholesterol instead of estra- diol). The rate of release of estradiol from the pellet was approximately $0.25 \mathrm{mg} /$ day (Innovative Research Inc., Sarasota, Fla., USA). Experiments were performed 5 days after surgery. Plasma estradiol concentrations were $62 \pm 6 \mathrm{pg} / \mathrm{ml}$ in the placebo-treated fetuses and $103 \pm 12 \mathrm{pg} / \mathrm{ml}$ in the estradiol-treated fetuses $(\mathrm{p}<0.001)$, as reported previously [9].

\section{Experiments}

We studied 4 groups ( $\mathrm{n}=4$ each): (1) control, (2) estradiol alone, (3) brachiocephalic occlusion (BCO) alone, and (4) estradiol plus BCO. Each fetus was subjected to a 10 -min period of BCO or sham-BCO (catheters manipulated but the balloon occluder was not inflated). Fetal arterial blood samples were drawn (5 ml each) at 0,10 , and 20 min after the onset of BCO. At each of these time points, $1 \mathrm{ml}$ of fetal blood was drawn anaerobically and heparinized for analysis of fetal blood gases, and $4 \mathrm{ml}$ was placed in a chilled tube containing $\mathrm{Na}_{4}$ EDTA for analysis of fetal plasma hormone concentrations, reported elsewhere [9]. At the start of each experiment (at $0 \mathrm{~min}$ ), an additional 5 - $\mathrm{ml}$ blood sample was drawn for the measurement of plasma estradiol concentrations.

Fetal lingual and femoral arterial blood pressure and fetal heart rate, measured continuously on-line, are reported elsewhere [9]. Fetal arterial blood pressure and blood gases were similar to those reported for fetal sheep in other studies. Brachiocephalic occlusion reduced lingual arterial blood pressure (measured downstream from the occlusion) in each fetus, consistent with the results of previous studies [6]. In the present study, this stimulus reduced fetal lingual arterial blood pressure from approximately $45 \mathrm{~mm} \mathrm{Hg}$ to approximately $15 \mathrm{~mm} \mathrm{Hg}$ [9]. Fetal blood gases were consistent with values previously recorded in this laboratory from chronically catheterized fetal sheep [6]. Values of $\mathrm{P}_{\mathrm{a}} \mathrm{O}_{2}$ in the present study were $19.1 \pm 0.8,18.6 \pm 1.1,19.3 \pm 1.4$, and $16.5 \pm 0.7$ $\mathrm{mm} \mathrm{Hg}$ in the control/control, $\mathrm{BCO} /$ control, control/estradiol, and $\mathrm{BCO} /$ estradiol groups, respectively [9].

One hour after the onset of BCO or sham-BCO, the ewe and fetus were humanely sacrificed using an overdose of sodium pentobarbital. The brain of the fetus was rapidly removed and dissected, and the brain regions of interest were rapidly frozen in liquid nitrogen, subsequently stored at $-80^{\circ} \mathrm{C}$, until processed. All tissues were analyzed for protein by Western blot, except for the pituitary because of the small total mass of tissue isolated from each animal. For isolation of protein, tissues were homogenized in 5 vol boiling lysis buffer ( $1 \%$ SDS, $1.0 \mathrm{~mm}$ sodium orthovanadate, $10 \mathrm{~mm}$ Tris $\mathrm{pH}$ 7.4), boiled, centrifuged to remove particulates, aliquoted, then stored at $-80^{\circ} \mathrm{C}$ until assayed. The protein concentration of the supernatant was measured using a modified Bradford method (BioRad Co., San Rafael, Calif., USA) using bovine serum albumin (Sigma Chemical, St. Louis, Mo., USA) as the standard [12]. For analysis, aliquots were thawed on ice, boiled, and electrophoresed. Electrophoresis was performed using a Criterion gel and transfer apparatus (BioRad) and precast $7.5 \%$ gels. The electrophoresed proteins were electroblotted onto nitrocellulose membranes $(0.45 \mu \mathrm{m}$ pore size, BioRad). After transfer to the nitrocellulose membrane, the blot was probed with polyclonal antibodies specific for ER- $\alpha$ or ER- $\beta$ for $1 \mathrm{~h}$. ER- $\alpha$ antibody (MC-20 antibody, cat. No. sc-542, Santa Cruz Biotechnology, Inc., Santa Cruz, Calif., USA) was diluted 1:200 in antibody diluent (PBS with $0.05 \%$ Tween 20 ) and ER- $\beta$ antibody (cat. No. PA1-311, Affinity BioReagents, Golden, Colo., USA) was diluted $1: 1,000$ in antibody diluent (5\% non-fat dry milk in PBS with 
Table 1. Estrogen receptor primer and probe sequences used in RT-PCR

\begin{tabular}{llll}
\hline Gene & Forward primer $\left(5^{\prime}-3^{\prime}\right)$ & Reverse primer $\left(5^{\prime}-3^{\prime}\right)$ & TaqMan probe \\
\hline ER- $\alpha$ & AGGCACACGGGAGCACAT & TTCCATGGGCTTGTAGAAGTCA & CTTCCCTTCCTTCTCACTGTCTCAGCCC \\
ER- $\beta$ & GCTCTGGTCTGGGTGATTGC & GTTAGCCAGGCGCATGGA & AAGAGCGGCATGTCCTCCCAGCA \\
\hline
\end{tabular}

0.05\% Tween 20, PBST). Membranes were visualized using goatperoxidase conjugated anti-rabbit IgG (Sigma Chemical Co.; 1:5,000 for ER- $\alpha$ and 1:10,000 for ER- $\beta$ ) and ECL reagent (Amersham, Arlington Heights, Ill., USA), and developed on film. Quantity One densitometry software (BioRad) was utilized for blot analysis. Molecular weight was calibrated using Rainbow ${ }^{\circledR}$ molecular weight markers (Amersham Co.). Staining specificity was confirmed by preabsorption of the primary antibody using $25 \mu \mathrm{g}$ ER- $\alpha$ synthetic peptide (Santa Cruz, cat. No. sc-542 P) or $25 \mu \mathrm{g}$ ER- $\beta$ synthetic peptide (Affinity BioReagents, cat. No. PA1-311).

All tissues were analyzed for messenger RNA (mRNA). We isolated mRNA using Trizol ${ }^{\circledR}$ (Gibco, Invitrogen Corp., Carlsbad, Calif., USA), according to the manufacturer's instructions. After isolation, we stored mRNA in RNA Secure ${ }^{\circledR}$ (Ambion Corp., Austin, Tex., USA) at $-80^{\circ} \mathrm{C}$ until use. Total mRNA in each sample $(4 \mu \mathrm{g})$ was converted to cDNA using the High Capacity cDNA Archive Kit using methodology recommended by the kit manufacturer (Applied Biosystems, Foster City, Calif., USA). The newly synthesized $\mathrm{cDNA}$, stored at $-20^{\circ} \mathrm{C}$, was used for the assay of mRNA abundance of several genes by real-time polymerase chain reaction.

ER- $\alpha$ and ER- $\beta$ primer and probe sets were designed on Primer Express version 2.0 (Applied Biosystems) from known ovine sequences (accession numbers AY059388 and NM_001009737, respectively) [13]. Sequences of ER- $\alpha$ and ER- $\beta$ probes and primers are reported in table 1. 18S ribosomal RNA was used as an internal control as previously described [14] and validated for developmental changes in gene expression in the developing brain [15]; primers and probe for $18 \mathrm{~S}$ rRNA were purchased from Applied Biosystems (cat. No. 4308329). ER- $\alpha$ and ER- $\beta$ reactions contained $100 \mathrm{ng}$ cDNA, $300 \mathrm{nM}$ forward primer, $900 \mathrm{nM}$ reverse primer, and $200 \mathrm{nM}$ Taqman ${ }^{\circledR}$ probe. Probes for ER- $\alpha$ and ER- $\beta$ were labeled with 6-carboxyfluoresceine in the $5^{\prime}$ position and carboxytetramethyl rhodamine (TAMRA) in the $3^{\prime}$ position. The probe for $18 \mathrm{~S}$ rRNA was labeled with $\mathrm{VIC}{ }^{\circledR}$ in the $5^{\prime}$ position and TAMRA in the $3^{\prime}$ position. Control reactions run at the same time indicate the primers were specific for our amplified product and that our RNA was not contaminated with genomic DNA. All reactions were performed in an ABI Prism 7000 Sequence Detection System (Applied Biosystems). Reactions were amplified using the following conditions: $48^{\circ} \mathrm{C}$ for $30 \mathrm{~min}$ and $95^{\circ} \mathrm{C}$ for 10 min, followed by 40 cycles of $95^{\circ} \mathrm{C}$ for $15 \mathrm{~s}$ and $60^{\circ} \mathrm{C}$ for $1 \mathrm{~min}$. Fold changes in expression levels of the ER- $\alpha$ or ER- $\beta$ genes within the brain regions of interest were calculated using the $2^{-\Delta \Delta C t}$ method [16] using $18 \mathrm{~S}$ rRNA as the internal reference.

Statistical Analysis

Data were analyzed by wo-way ANOVA (SPSS v. 15.0, SPSS Inc., Chicago, Ill., USA). Pairwise comparisons were made using the Bonferroni method. To eliminate between-gel variability in Western blots, all samples from a single brain region were run on a single gel. Statistical significance was assessed using a criterion of $\mathrm{p}<0.05$.

\section{Results}

Both BCO and estradiol treatments were effective in changing estrogen receptor expression, although the effect of each treatment was limited to specific regions. BCO dramatically increased ER- $\alpha$ expression in the pituitary and both ER- $\alpha$ and ER- $\beta$ expression in the brainstem, while decreasing ER- $\alpha$ expression in the hypothalamus. Estradiol treatment decreased ER- $\alpha$ expression in the hypothalamus, whereas it increased ER- $\alpha$ expression in the brainstem, cerebral cortex, and hippocampus.

In the pituitary, $\mathrm{BCO}$ increased the abundance of ER- $\alpha$ mRNA (fig. 1). The effect of BCO on ER- $\alpha$ mRNA was statistically significant ( $p<0.05$, main effect of BCO; two-way ANOVA), while the effect of estradiol was not $(\mathrm{p}=\mathrm{NS}$ for main effect of estradiol and for BCO $\times$ estradiol interaction). ER- $\beta$ mRNA was not significantly changed by either treatment, either alone or in combination ( $\mathrm{p}=\mathrm{NS}$; 2-way ANOVA; table 2). Protein was not available from the pituitary for analysis of abundance of ER forms.

In the brainstem, there was a strong stimulatory effect of BCO on both ER- $\alpha$ and ER- $\beta$ at both the mRNA and protein levels (fig. 1). Estradiol treatment increased ER- $\alpha$ protein in the absence of a change in mRNA. Both ER- $\alpha$ and ER- $\beta$ mRNA abundance were increased by BCO $(\mathrm{p}=0.001$ and 0.002 , respectively, for the main effect of BCO; 2-way ANOVA) (fig. 1; table 2). Neither mRNA transcript was altered significantly by estradiol treatment $(\mathrm{p}=$ NS for main effect of estradiol and $\mathrm{BCO} \times$ estradi$\mathrm{ol}$ ). At the protein level, there was a statistically significant interaction between $\mathrm{BCO}$ and estradiol with regard to ER- $\alpha$ abundance $(\mathrm{p}<0.05$ for $\mathrm{BCO} \times$ estradiol interaction), although the effect of $\mathrm{BCO}$ alone was not significant. Accompanying the changes in ER- $\alpha$ protein, there was a statistically significant main effect of BCO on ER- $\beta$ 


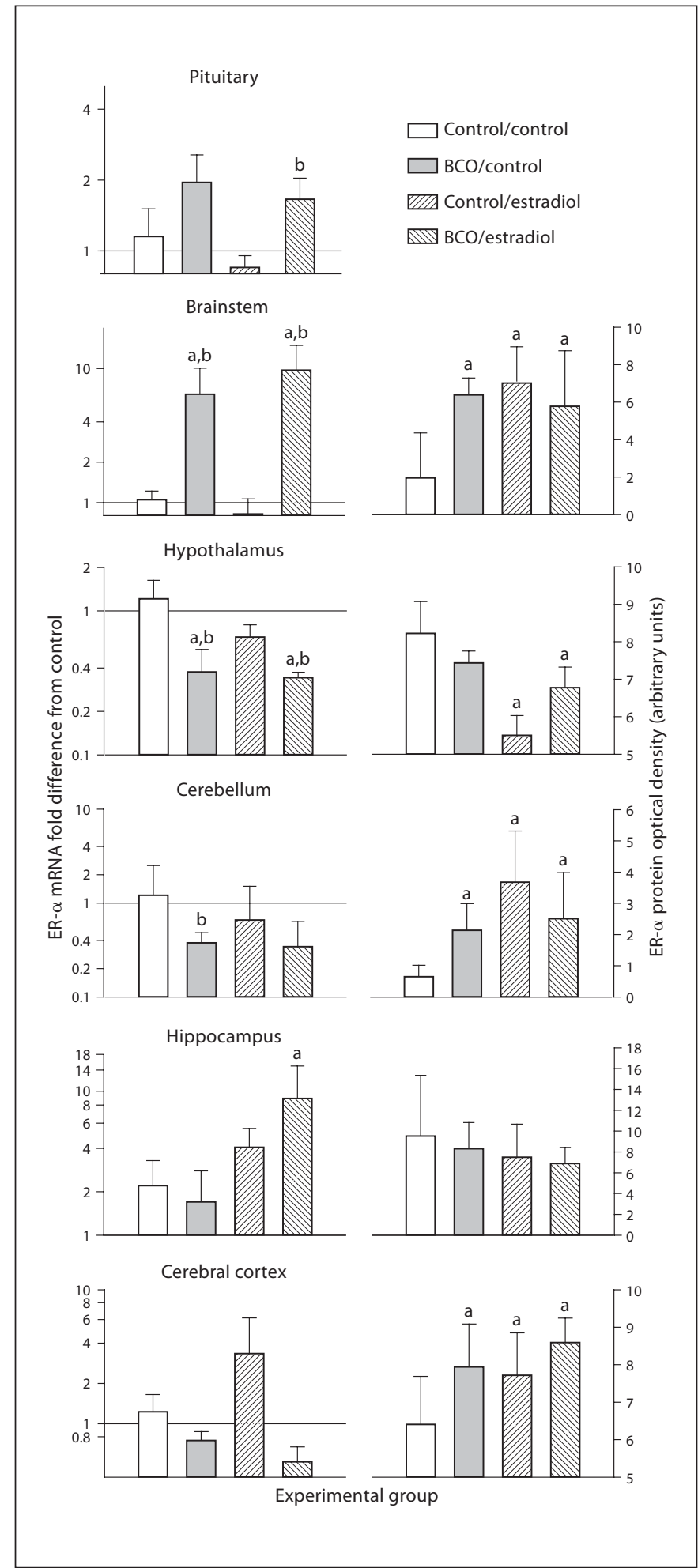

Fig. 1. ER- $\alpha$ mRNA (left) and protein (right) abundance in fetal brainstem, hypothalamus, cerebellum, hippocampus and cerebral cortex, and ER- $\alpha$ mRNA only in pituitary. mRNA abundances are expressed as fold changes from mean control (no estradiol and no BCO) values as calculated from the individual $\Delta \Delta \mathrm{Ct}$ val- protein ( $<<0.05$ for main effect of BCO; ANOVA) (fig. 2; table 2).

In the hypothalamus, there were no statistically significant effects of BCO or estradiol treatment on the abundance of ER- $\alpha$ (fig. 1) or ER- $\beta$ mRNA (table 2), although the effect of BCO on ER- $\alpha$ was close ( $p=0.06$ for main effect of BCO). Decreases in ER- $\alpha$ mRNA after $\mathrm{BCO}$ (relative to non-BCO groups in both placebo and estradiol-treated fetuses) in the hypothalamus were detected using the Bonferroni test (fig. 1). At the protein level in the hypothalamus, there was a statistically significant downregulation of ER- $\alpha$ protein by estradiol treatment ( $p<0.05$ for main effect of estradiol; two-way ANOVA), but no significant effect of either BCO or BCO $\times$ estradiol interaction (fig. 1 ). ER- $\beta$ protein abundance was below the limit of sensitivity and therefore was not analyzed.

In the hippocampus, there was a statistically significant effect of estradiol on ER- $\alpha$ mRNA abundance ( $p=$ 0.05 for main effect of estradiol; two-way ANOVA), but no significant effect of $\mathrm{BCO}$ or $\mathrm{BCO} \times$ estradiol interaction (fig. 1). Comparison of groups using the Bonferroni test revealed a statistically significant increase in ER- $\alpha$ mRNA in response to estradiol and BCO compared to untreated fetuses (fig. 1). Neither treatment significantly altered ER- $\beta$ mRNA abundance (table 2 ). Only ER- $\alpha$ protein was measurable at this gestational age in the hippocampus. ER- $\alpha$ protein abundance was not altered by either treatment (fig. 1).

In the cerebellum and in cerebral cortex, neither ER- $\alpha$ nor ER- $\beta$ mRNA was significantly altered by either treatment, as tested by ANOVA (fig. 1; table 2). A significant decrease in ER- $\alpha$ mRNA was identified by the Bonferroni test (fig. 1). Interestingly, ER- $\alpha$ protein abundance in the cerebellum was significantly increased by both treatments ( $p<0.05$ for both the main effect of estradiol and for $\mathrm{BCO} \times$ estradiol interaction in ANOVA). Comparison of groups using the Bonferroni test demonstrated that both estradiol and BCO increased ER- $\alpha$ protein in cerebral cortex above that in untreated fetuses, and that there was no added stimulation when the two treatments were combined (fig. 1).

ues and represented graphically in logarithmic bar graphs. Values are represented as mean \pm SEM. ${ }^{a}$ Statistically significant differences from control/control values; ${ }^{b}$ significant differences from control/estradiol values. 
Table 2. ER- $\beta$ mRNA responses to estradiol and BCO

\begin{tabular}{lcccc}
\hline Tissue & Control/control & BCO/control & Control/estradiol & BCO/estradiol \\
\hline Pituitary & $0.00 \pm 0.26$ & $-0.24 \pm 0.30$ & $0.18 \pm 0.19$ & $-0.91 \pm 0.40$ \\
Hypothalamus & $0.00 \pm 0.45$ & $1.87 \pm 0.54$ & $0.64 \pm 0.35$ & $1.60 \pm 0.16$ \\
Cerebellum & $0.00 \pm 0.95$ & $1.68 \pm 0.39$ & $0.06 \pm 0.95$ & $0.99 \pm 0.74$ \\
Brainstem & $0.00 \pm 0.22$ & $-2.15 \pm 0.72^{\mathrm{a}}$ & $0.50 \pm 0.55$ & $-2.83 \pm 0.72^{\mathrm{a}}$ \\
Cortex & $0.00 \pm 1.27$ & $1.07 \pm 0.43$ & $-0.08 \pm 1.26$ & $1.07 \pm 0.43$ \\
Hippocampus & $0.00 \pm 1.24$ & $0.06 \pm 0.95$ & $-1.55 \pm 0.60$ & $-2.24 \pm 0.86$ \\
\hline
\end{tabular}

Data are represented as mean \pm SEM of $\Delta \Delta \mathrm{Ct}$ relative to the mean $\Delta \mathrm{Ct}$ of the control/control group in each tissue.

a Statistically significant effect of BCO.

\section{Discussion}

The results of the present study demonstrate that the abundance of estrogen receptors in the brain and pituitary of late-gestation fetal sheep are sensitive to both prevailing concentrations of estradiol in the plasma and to the prior exposure to cerebral hypoperfusion. Interestingly, the regulation of receptor abundance is region-specific, and the data are consistent with regulation of protein abundance independent of mRNA levels.

\section{Brachiocephalic Occlusion}

This is the first study to demonstrate changes in brain estrogen receptor abundance in response to cerebral hypoperfusion in the fetus. This effect of $\mathrm{BCO}$ was restricted to the pituitary, brainstem, hypothalamus, and cerebellum. This is not likely caused by more dramatic changes in flow in these regions, as we have previously found that changes in blood flow in these regions is similar to that in the other areas [6]. The influence of BCO on estrogen receptor abundance was consistent with the effect of middle cerebral artery occlusion on estrogen receptor abundance in rats and mice [17]. It is possible that the expression of estrogen receptors, especially by glia, is a common feature of the brain response to injury $[18,19]$. In a recent study by Dubal et al. [17], ER- $\alpha$ was induced in the cerebral cortex at both the mRNA and protein levels. The earliest time point investigated in that study was $4 \mathrm{~h}$; nevertheless, the induction of ER- $\alpha$ was long-lasting (at least $24 \mathrm{~h}$ ). In that study, ER- $\beta$ was induced by middle cerebral artery occlusion only after pretreatment with estradiol. In adult animals, estrogen is neuroprotective [20], and it is possible that upregulation of the ER- $\alpha$ in the brainstem in the current study represents a mechanism for protection against damage caused by a second ischemic event.

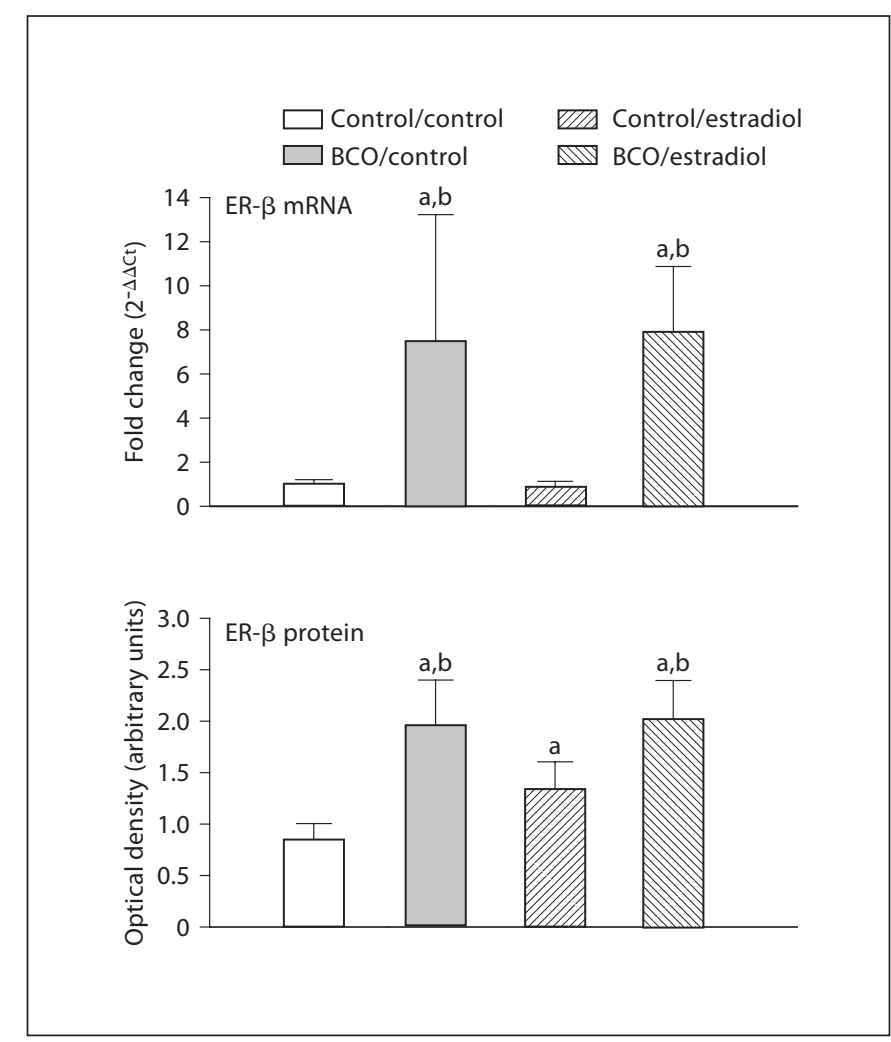

Fig. 2. ER- $\beta$ mRNA (top) and protein (bottom) abundance in fetal brainstem. mRNA abundances are expressed as fold changes from the mean control (no estradiol and no BCO) values as calculated from the individual $\Delta \Delta \mathrm{Ct}$ values and represented graphically in logarithmic bar graphs. Values are represented as mean \pm SEM. ${ }^{\text {a }}$ Statistically significant differences from control/control; ${ }^{\mathrm{b}}$ significant differences from control/estradiol. 


\section{Estradiol}

Regulation of estrogen receptors in brain by estradiol is not completely understood. In female rats, estradiol treatment downregulated estrogen receptor binding in the hypothalamus and amygdala [3, 4]. Long-term (3 months) ovariectomy in rats downregulated brain ER- $\beta$ but did not alter abundance of ER- $\alpha$ [21]. In the short term (minutes), estrogen treatment in rats decreases cytoplasmic ER abundance [22], an effect that may be accounted for by translocation of the bound receptor to the nucleus [23]. In another study, ER- $\beta$ mRNA was downregulated by estrogen treatment (compared to ovariectomized rats) in the olfactory bulb, entorhinal cortex, lateral septal nucleus, amygdala, thalamus, medial geniculate nucleus, suprachiasmatic nucleus, and Purkinje cells of the cerebellum [24]. In the uterus, ER- $\alpha[25,26]$ and ER- $\beta$ [27] abundance is downregulated by estrogen treatment.

This is the first study to investigate the influence of estradiol on estrogen receptor abundance in the brain and the pituitary of the fetus. In this study, we aimed to investigate the effect of physiological increases in fetal plasma estradiol concentration on estrogen receptor abundance, in contrast to pharmacologic exposure that would not be experienced in vivo. Estradiol downregulated ER- $\alpha$ in the hypothalamus statistically significantly at the protein level and almost statistically significantly at the mRNA level. The downregulation of this receptor in the fetal hypothalamus is reminiscent of the downregulation of ER in hypothalamic nuclei in adult rats exposed to large doses of estradiol $[3,4]$. In contrast to the effect in the hypothalamus, estradiol increased ER- $\alpha$ in the hippocampus (at the mRNA level) and cerebellum (at the protein level).

\section{$m R N A$ versus Protein Abundance}

In several circumstances, there was a discordance between mRNA and protein abundance. This is apparent in the brainstem after estradiol treatment, for example. In this region, estradiol treatment appeared not to change the abundance of mRNA but increased the abundance at the protein level. In the cerebellum, BCO decreased the mRNA abundance for ER- $\alpha$ but significantly increased the abundance of the protein. We interpret these data as suggesting that there is quantitatively significant regulation of the abundance of the protein independent of mRNA. This could happen by alteration of the rate of degradation of the receptor. ER- $\alpha$ is ubiquitinated and degraded in the proteasome $[28,29]$. Cerebral ischemia is known to alter proteasomal activity [30,31], suggesting the possibility that changes in the rate of receptor degra- dation might alter the concentration of receptor protein relative to receptor mRNA in the hours following BCO. At the mRNA level, ER- $\alpha$ mRNA is rapidly degraded [32]; the rate of degradation is influenced by binding of RNAbinding proteins to $3^{\prime}$ terminal AU-rich regions [33]. Indeed, it is possible that the increase in ER- $\alpha$ in response to BCO in the present experiments might result from decreases in the rate of degradation of the mRNA.

\section{Conclusions}

We conclude that estrogen receptors are dynamically regulated in the brain of late-gestation sheep fetuses. Exposure of the fetus to physiological increases in plasma estradiol concentrations downregulates ER- $\alpha$ in the hypothalamus, and paradoxically upregulates ER- $\alpha$ in the hippocampus and augments the ER- $\alpha$ response to BCO in the brainstem. Cerebral hypoperfusion dramatically upregulates both ER- $\alpha$ and ER- $\beta$ in the fetal brainstem. These responses demonstrate that the regulation of estrogen receptors in the fetal brain is region-specific. The data suggest that the ovine fetal brain responds to changes in the physiological state of the fetus by changing regional sensitivity to estrogen. We had previously proposed that estrogen, secreted by the placenta and circulating in the fetal plasma, is an important modulator of fetal HPA axis responses to stress. The present results suggest that changes in brain receptor content may be a neuroendocrine regulator that is as important as changes in plasma estradiol concentration.

\section{Acknowledgements}

This work was supported by HD42135 and HD33053. I thank Ms. Xiaoying (Lisa) Fang for her expert technical help, and Damian Giroux, PhD for his work on the in vivo aspects of this work.
References
1 Schaub C, Wood CE: Ontogeny of ER-alpha and ER-beta in Ovine Brain. Journal of the Society for Gynecologic Investigation. 2004;11:129A.
2 Hatsumi T, Yamamuro Y: Downregulation of estrogen receptor gene expression by ex- ogenous 17beta-estradiol in the mammary glands of lactating mice. Exp Biol Med (May- wood) 2006;231:311-316.
- 3 Brown TJ, Scherz B, Hochberg RB, Mac- Lusky NJ: Regulation of estrogen receptor concentrations in the rat brain: effects of sus- tained androgen and estrogen exposure. Neuroendocrinology 1996;63:53-60. 
4 Simerly RB, Young BJ: Regulation of estrogen receptor messenger ribonucleic acid in rat hypothalamus by sex steroid hormones. Mol Endocrinol 1991;5:424-432.

-5 Schreihofer DA, Stoler MH, Shupnik MA: Differential expression and regulation of estrogen receptors (ERs) in rat pituitary and cell lines: estrogen decreases ERalpha protein and estrogen responsiveness. Endocrinology 2000;141:2174-2184.

-6 Tong H, Wood CE: Indomethacin attenuates the cerebral blood flow response to hypotension in late-gestation fetal sheep. Am J Physiol 1999;277:R1268-R1273.

7 Purinton SC, Wood CE: Oestrogen augments the fetal ovine hypothalamus-pituitary-adrenal axis in response to hypotension. J Physiol 2002;544:919-929.

8 Dubal DB, Wilson ME, Wise PM: Estradiol: a protective and trophic factor in the brain. J Alzheimers Dis 1999;1:265-274.

$\checkmark 9$ Wood CE, Giroux D: Central nervous system prostaglandin endoperoxide synthase-1 and -2 responses to oestradiol and cerebral hypoperfusion in late-gestation fetal sheep. J Physiol 2003;549:573-581.

$\checkmark 10$ Wood CE, Giroux D: Expression of nitric oxide synthase isoforms in the ovine fetal brain: alteration by hormonal and hemodynamic stimuli. J Soc Gynecol Investig 2006;13:329337.

-11 Wood CE, Giroux D, Gridley K: Fetal brain regional responses to cerebral hypoperfusion: modulation by estrogen. Brain Res 2003;993:84-89.

12 Bradford MM: A refined and sensitive method for the quantitation of microgram quantities of protein utilizing the principle of protein-dye binding. Analytical Biochem 1976; 72:248-254.

13 Byers MJ, Zangl A, Phernetton TM, Lopez G, Chen DB, Magness RR: Endothelial vasodilator production by ovine uterine and systemic arteries: ovarian steroid and pregnancy control of ERalpha and ERbeta levels. J Physiol 2005;565:85-99.
14 Wood CE, Cousins R, Zhang D, Keller-Wood M: Ontogeny of expression of organic anion transporters 1 and 3 in ovine fetal and neonatal kidney. Exp Biol Med (Maywood) 2005; 230:668-673.

15 Al-Bader MD, Al-Sarraf HA: Housekeeping gene expression during fetal brain development in the rat-validation by semi-quantitative RT-PCR. Brain Res Dev Brain Res 2005; 156:38-45.

16 Livak KJ, Schmittgen TD: Analysis of relative gene expression data using real-time quantitative PCR and the 2(-delta delta C(T)) method. Methods 2001;25:402-408.

17 Dubal DB, Rau SW, Shughrue PJ, Zhu H, Yu J, Cashion AB, Suzuki S, Gerhold LM, Bottner MB, Dubal SB, Merchanthaler I, Kindy MS, Wise PM: Differential modulation of estrogen receptors (ERs) in ischemic brain injury: a role for ERalpha in estradiolmediated protection against delayed cell death. Endocrinology 2006; 147:3076-3084.

18 Blurton-Jones M, Tuszynski MH: Reactive astrocytes express estrogen receptors in the injured primate brain. J Comp Neurol 2001; 433:115-123.

19 Garcia-Ovejero D, Veiga S, Garcia-Segura LM, Doncarlos LL: Glial expression of estrogen and androgen receptors after rat brain injury. J Comp Neurol 2002;450:256-271.

$\checkmark 20$ Wise P: Estradiol exerts neuroprotective actions against ischemic brain injury: insights derived from animal models. Endocrine 2003;21:11-15.

21 Rose'Meyer RB, Mellick AS, Garnham BG, Harrison GJ, Massa HM, Griffiths LR: The measurement of adenosine and estrogen receptor expression in rat brains following ovariectomy using quantitative PCR analysis. Brain Res Brain Res Protoc 2003;11:918.

22 Blaustein JD: Estrogen receptor immunoreactivity in rat brain: rapid effects of estradiol injection. Endocrinology 1993;132:12181224.

23 Parikh I, Rajendran KG, Su JL, Lopez T, Sar M: Are estrogen receptors cytoplasmic or nuclear? Some immunocytochemical and biochemical studies. J Steroid Biochem 1987; 27:185-192.
24 Shima N, Yamaguchi Y, Yuri K: Distribution of estrogen receptor beta mRNA-containing cells in ovariectomized and estrogen-treated female rat brain. Anat Sci Int 2003;78:8597.

25 Tschugguel W, Dietrich W, Zhegu Z, Stonek F, Kolbus A, Huber JC: Differential regulation of proteasome-dependent estrogen receptor alpha and beta turnover in cultured human uterine artery endothelial cells. J Clin Endocrinol Metab 2003;88:2281-2287.

26 Medlock KL, Forrester TM, Sheehan DM: Short-term effects of physiological and pharmacological doses of estradiol on estrogen receptor and uterine growth. J Recept Res 1991;11:743-756

27 Skrzypczak M, Bieche I, Szymczak S, Tozlu S, Lewandowski S, Girault I, Radwanska K, Szczylik C, Jakowicki JA, Lidereau R, Kaczmarek L: Evaluation of mRNA expression of estrogen receptor beta and its isoforms in human normal and neoplastic endometrium. Int J Cancer 2004;110:783-787.

28 Nirmala PB, Thampan RV: Ubiquitination of the rat uterine estrogen receptor: dependence on estradiol. Biochem Biophys Res Commun 1995;213:24-31.

29 Nawaz Z, Lonard DM, Dennis AP, Smith CL, O'Malley BW: Proteasome-dependent degradation of the human estrogen receptor. Proc Natl Acad Sci USA 1999;96:1858-1862.

30 Ceremuga TE, Yao XL, Alam HB, McCabe JT: Alterations of cullin-5 mRNA levels in the rat central nervous system following hemorrhagic shock. Neurol Res 2003;25: 211-216.

31 Wojcik C, Di NM: Ubiquitin-proteasome system and proteasome inhibition: new strategies in stroke therapy. Stroke 2004;35: 1506-1518.

32 Kenealy MR, Flouriot G, Sonntag-Buck V, Dandekar T, Brand H, Gannon F: The 3'-untranslated region of the human estrogen receptor alpha gene mediates rapid messenger ribonucleic acid turnover. Endocrinology 2000;141:2805-2813.

33 Malter JS: Identification of an AUUUA-specific messenger RNA binding protein. Science 1989;246:664-666. 